Article

\title{
Climate Change Challenges to Existing Cultural Heritage Policy
}

\author{
Ahmadreza Shirvani Dastgerdi * (1), Massimo Sargolini $(1)$ and Ilenia Pierantoni $(\mathbb{D}$ \\ School of Architecture and Design, University of Camerino, Viale delle Rimembranze, 63100 Ascoli Piceno, Italy; \\ Massimo.sargolini@unicam.it (M.S.); Ilenia.pierantoni@unicam.it (I.P.) \\ * Correspondence: Ahmadreza.shirvani@unicam.it
}

Received: 1 September 2019; Accepted: 18 September 2019; Published: 24 September 2019

\begin{abstract}
Climate change affects, directly and indirectly, the tangible and intangible features of heritage sites. Conservation studies often examine the impacts of climate change on heritage sites by assuming it as an isolated and static concept. This study aims to debate cultural heritage concept as the primary and neglected factor for wise development of climate-resilience policies. We first adopt the qualitative Meta-synthesis method to analyze the impacts of climate change on world heritage sites, through a systematic review of reports published by the UNESCO and its advisory bodies. Then, it is explained why the sustainability of cultural heritage requires a fundamental reconsideration of the concept and promotion of its evaluation framework. The findings suggest that protection of cultural heritage and developing the climate-resilience policies for the sustainability of landscape requires at the early stages a reflection on how heritage is defined as a useful resource and acceptable characteristic of territory.
\end{abstract}

Keywords: cultural heritage; climate change; conservation; climate resilience; protection; sustainability; territorial planning

\section{Introduction}

Nowadays, there is an increasing concern over climate change effects, and there is irrefutable evidence that suggests that humans might be directly responsible for the emergence of this phenomenon [1]. A change in weather pattern would lead to destabilization of social and environmental conditions [2], and these disruptions could threaten the sustainability of natural and socio-economic systems [3]. Heritage sites can be vulnerable to changes in weather patterns [4], not only restricted to direct impacts on the built structure [5], but also having very indirect consequences like fragmentations of populations, loss of intangible features [6], declining in visitor numbers, and disruption of socio-economic activities [7]. Climate change is likely to affect cultural diversity and socio-cultural interactions by forcing communities to change their work habits and ways of life [8], to compete for resources or to migrate elsewhere [9], under the different type of climate-driven disasters like desertification, flooding or sea-level rise [10]. The impacts of climate change on the loss of social community [11], traditional knowledge, cultural identity [12] or natural and socio-economic systems [13] have well documented but few studies have considered climate impacts on cultural heritage sites [14].

From the urban and regional planning point of view, most conservation studies consider the concept of cultural heritage as a static object [15], and have usually defined it based on the principles of the World Heritage Convention which adopted by the United Nations Educational, Scientific and Cultural Organization (UNESCO) in 1972 [16]. Climate change itself is a new challenge for UNESCO, and the organizational solutions for the conservation of heritage sites are at an early step [17]. Policymakers and site managers should take into account both heritage and climate change are dynamic fields of investigation [18], and the associated socio-economic changes will have a more significant 
impact on the protection of heritage than climate change alone [19]. This study, therefore, aims to initiate a debate about the concept of cultural heritage as the primary step in the development of climate-resilience policies for heritage sites, while climate change is transforming the social, economic, and political dynamics across different geographies [20]. The efficiency of climate-resilience policies are not visible in the short term [21], and therefore, the way that the concept of cultural heritage defines under the spotlight of climate change would be in great importance for the protection of cultural heritage and consequently for the sustainability of the landscape [22].

\section{Theoretical Framework}

The World Heritage Convention has been in force since 1975 to conserve and transmit the cultural and natural heritage of outstanding universal value to future generations. Meeting the criteria of outstanding universal value is the significant factor for inclusion of cultural and natural assets in the World Heritage List, which are assessed through a rigorous evaluation method by the Advisory Bodies of the Convention [16]. This concept, however, has been the subject of criticism by scholars from various point of view [23], such as the applied method for defining the outstanding universal value [24] or cultural values [25], the measuring tools for authenticity and integrity [26], the efficiency of management plan [27], the quality of place image [28,29] and consequently the tourists perceptions and satisfaction of a World Heritage Site [30]. Conservation of heritage sites has also been accompanied by various challenges such as the pressure of globalization on historic cities [31], damaged as a result of major escalations of armed conflict [32], and transformation of the historic landscape as a result of religious differences [33,34]. Over the past decades, many conventions, charters and guidelines have evolved by UNESCO and its advisory bodies (The International Union for the Conservation of Nature (IUCN), the International Council on Monuments and Sites (ICOMOS), and the International Centre for the Study of the Preservation and Restoration of Cultural Property (ICCROM)) to correspond better to the perception of cultural heritage and evolving the conservation policies [35].

At its 29th session in 2005, The World Heritage Committee recognized climate change as an emerging threat to the conservation of many cultural and natural sites in the years ahead. The year 2006 marked the beginning of a new chapter in cultural heritage conservation when a report on 'Predicting and managing the effects of climate change on world heritage' [36] and a 'Strategy to assist states parties to implement appropriate management responses' [10] was presented to the World Heritage Committee at it 30th session in Lithuania. To address the climate change impacts, nearly 50 climate scientists and World Heritage specialists came together in this meeting, including representatives from the Intergovernmental Panel on Climate Change (IPCC), the United Nations Framework Convention on Climate Change (UNFCCC), the United Nations Environment Program (UNEP), the World Resources Institute (WRI), and the Advisory Bodies to the World Heritage Convention [12].

Changing in the weather pattern is primarily a threat that has physical impacts. It affects cultural heritage through temperature changes, soil erosion, flooding and storms as well as natural heritage through the melting of glaciers and habitat changes [37]. It can also force populations to migrate, leading to the break-up of communities and the abandonment of property, with the eventual loss of rituals and cultural memory. As far as the conservation of cultural heritage is concerned, this abandonment raises a significant concern in contexts where traditional knowledge and skills are essential to ensure the proper maintenance of these properties [12]. As an international organization, UNESCO also faces institutional challenges in the context of climate change that call for closer co-operation between the different Program Sectors Education, Sciences, Culture and Communication and Information [38], and therefore, a more determined reaction by UNESCO to climate change is wanting [39].

Climate change can be perceived as a driving factor in the evolution of conservation policies. Furthermore, revising the concept of cultural heritage can be seen as a critical factor in the effectiveness of climate-resilience policies, while climate change is transforming social, economic and political dynamics with a degree of uncertainty. 


\section{Materials and Methods}

This study adopts a qualitative Meta-synthesis method in its procedure, focusing on selecting qualitative studies on a specific body of knowledge and translating those findings into one interpretation offering a more productive and a complete understanding of the phenomenon [40]. In this study, first, climate change impacts on world heritage sites were analyzed through a systematic review of reports published by the UNESCO and its advisory bodies. Using systematic review method enable researchers to identify, critically evaluate and integrating the findings of all relevant, high-quality individual studies addressing one or more research questions. This method, therefore, is able to address much broader questions than single empirical studies ever can [41]. The selected documents in this section are listed in Table 1.

Table 1. The analyzed reports published by the UNESCO and its advisory bodies.

\begin{tabular}{cccc}
\hline No. & Report Name & Publisher & Year \\
\hline 1 & Predicting and managing the effects of climate change on World Heritage & UNESCO & 2006 \\
2 & Case studies on climate change and world heritage & UNESCO & 2007 \\
3 & World Heritage and tourism in a changing climate & UNESCO & 2016 \\
4 & Future of our pasts: engaging cultural heritage in climate action & ICOMOS & 2019 \\
\hline
\end{tabular}

We then explain why the sustainability of cultural heritage requires a fundamental reconsideration of the concept and promotion of its value assessment framework to support the effectiveness of climate-resilience policies.

\section{Results}

According to the IPCC, the unusual rate of increase in global temperature that has been reported during the 20th century is the highest in the last millennium, and most of this rise is attributable to human activities [36]. The general absence of cultural heritage from the climate discourse has a practical, correlative reality: while the culture and heritage sectors are important institutions in most communities, they often are not directly engaged in the work of climate action [42]. In 2005, a study was conducted by the World Heritage Centre among all State Parties to the World Heritage Convention to assess the impacts of change in weather pattern on World Heritage sites. The collected responses reveal that climate change had an impact on $72 \%$ of the natural and cultural heritage sites in the sampled countries. Forty-six countries out of 83 , mentioned that they were beginning specific procedures to manage the issue, although most of these actions were limited to the monitoring of the impacts. Thirty-nine countries reported that dedicated examination was underway. Forty-nine states also declared that political support was being mobilized, although this usually concerned awareness-raising actions. A total of 125 World Heritage Sites were mentioned as threatened by climate change. Seventy-nine of these cases were natural-mixed sites (Figure 1).

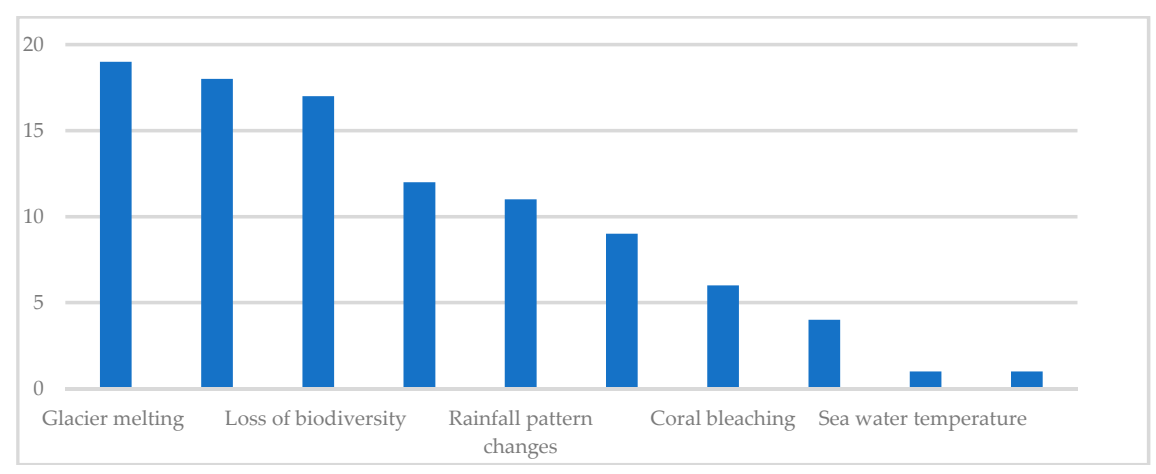

Figure 1. The climate change impacts observed for natural World Heritage properties, derived from [37]. 
Climate change threats on 46 Cultural World Heritage sites were reported. Almost all cultural sites mentioned were "human-built structures", like archaeological ruins, churches, mosque or temples, and only four sites referred to cultural landscapes (Figure 2).

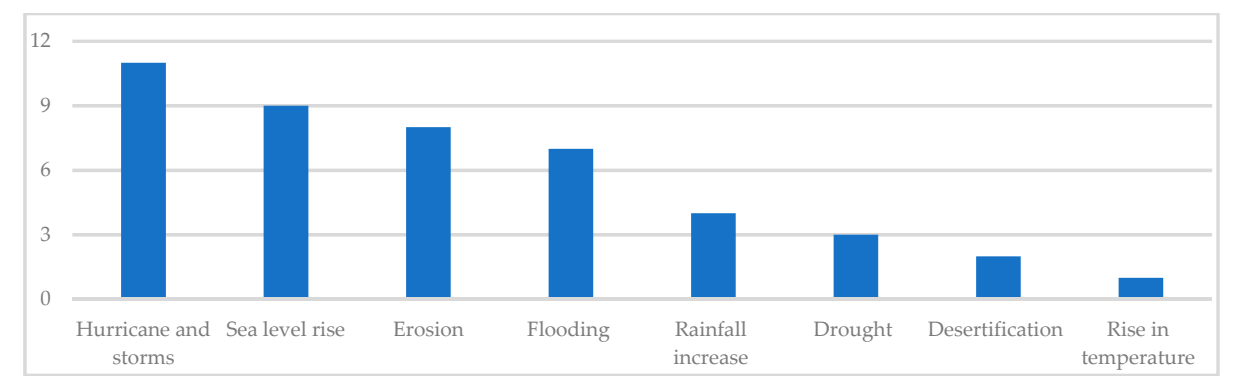

Figure 2. The climate threats raised for cultural world heritage sites, derived from [37].

\subsection{Impacts of Climate Change on Natural World Heritage}

Environmental and biological changes affect ecosystem functioning and the provision of ecosystem goods and services with significant consequences on human livelihoods. Therefore, socio-economic activities like agriculture, fishery or tourism are also being impacted, for instance, through changes in freshwater supply. The interaction between climate change and other global drivers like land-use change, potentially exacerbate adverse impacts on people and their environment. As far as terrestrial biodiversity is concerned, change in weather pattern will impact a wide range of biomes. The annual melt of mountainous glacier also drives the hydrological cycles of the region. As the ice recedes, however, there will first be floods, and sometime later, water supply will cease to be available, eventually leading to famine and pandemic disease. The rise of ocean temperature threatens many marine species among which coral reefs that, in many areas, live near to their upper thermal limit.

\subsection{Impacts of Climate Change on Cultural World Heritage}

Ancient buildings were designed for a specific local climate, and they have greater intimacy with the ground than modern ones. They are more porous and draw water from the ground into their structure and lose it to the environment by surface evaporation. Increases in soil moisture might result in more notable salt mobilization and result in damaging crystallization on decorated facades through drying. Organic materials like timber may be subject to increased biological infestation such as migration of pests in latitudes and altitudes that may not have been before affected by such threats. Increasing sea level threatens many coastal sites. Also, the conditions for the conservation of archaeological evidence may be degraded in the context of increasing soil temperature.

Increases in wind and storm activity can lead to structural damage, and salt weathering and erosion will threaten cultural heritage in desertic areas like the Chinguetti Mosque in Mauritania. However, aside from these physical threats, climate change will impact on cultural and social aspects, with communities changing the way they live. Many World Heritage sites are living places which depend on their inhabitants to be sustained and maintained.

\subsection{Additional Stress}

Climate change is a severe threat to the long-term conservation of the values at the heritage sites. However, this threat must be considered as one of many issues. At each site, there are a series of pressures which require active management solutions at the local level, for instance water stress across the region and impact on people and biodiversity in many ways. Therefore, the resilience of many heritage sites to climate change can be significantly improved also by reducing the effects of other stresses. Table 2 contains information on the impact of climate on both natural and cultural heritage sites, including the additional source of stress for each. 
Table 2. Impacts of climate change on world heritage sites derived from [13].

\begin{tabular}{|c|c|c|c|c|}
\hline Type & & Case Study & Climate Change Impact & Additional Stress \\
\hline \multirow{14}{*}{ Natural } & \multirow{5}{*}{ Glaciers } & Sagarmatha Park, Nepal & \multirow{5}{*}{$\begin{array}{l}\text { - Sudden and violent flooding in the } \\
\text { downstream valleys } \\
\text { - } \quad \text { Geological and hydrological impacts } \\
\text { Threatening mountainous } \\
\text { ecosystems and } \\
\text { terrestrial biodiversity }\end{array}$} & \multirow{5}{*}{$\begin{array}{l}\text { - } \quad \text { locally triggered pressures } \\
\text { desource and } \\
\text { development pressures } \\
\text { the long-term conservation } \\
\text { challenge and necessity for } \\
\text { management solutions at the } \\
\text { local level }\end{array}$} \\
\hline & & $\begin{array}{c}\text { Huascarán National Park, } \\
\text { Peru }\end{array}$ & & \\
\hline & & Ilulissat Icefjor, Denmark & & \\
\hline & & $\begin{array}{l}\text { Kilimanjaro National Park, } \\
\text { United Republic of Tanzania }\end{array}$ & & \\
\hline & & $\begin{array}{l}\text { Jungfrau-Aletsch-Bietschhorn, } \\
\text { Switzerland }\end{array}$ & & \\
\hline & \multirow{3}{*}{$\begin{array}{c}\text { Marine } \\
\text { Biodiversity }\end{array}$} & Great Barrier Reef, Australia & \multirow{3}{*}{$\begin{array}{ll}\text { - } & \text { Changing migratory patterns } \\
\text { - } & \text { Shifting community composition } \\
\text { - } & \text { Changing ecosystem functioning }\end{array}$} & \multirow{3}{*}{$\begin{array}{l}\text { - } 58 \% \text { of coral reefs are } \\
\text { considered at risk of episodic } \\
\text { natural events and } \\
\text { human activities }\end{array}$} \\
\hline & & $\begin{array}{l}\text { Sundarbans, India, } \\
\text { Bangladesh }\end{array}$ & & \\
\hline & & $\begin{array}{l}\text { Komodo National Park, } \\
\text { Indonesia }\end{array}$ & & \\
\hline & \multirow{6}{*}{$\begin{array}{l}\text { Terrestrial } \\
\text { Biodiversity }\end{array}$} & Cape Floral Region, South & \multirow{6}{*}{$\begin{array}{l}\text { - Local, regional, and global extinction } \\
\text { of species due to range expansions, } \\
\text { contractions and eliminations } \\
\text { Altering in the phenology, nutrient } \\
\text { cycling and availability of } \\
\text { natural resource }\end{array}$} & \multirow{6}{*}{$\begin{array}{l}\text { - } \text { Strengthening the risk } \\
\text { preparedness such as } \\
\text { fire seasonality } \\
\text { - forces of change in land use } \\
\text { - The necessity for formulating } \\
\text { feasible proactive } \\
\text { regional-scale } \\
\text { management initiatives }\end{array}$} \\
\hline & & Africa & & \\
\hline & & $\begin{array}{c}\text { Greater Blue } \\
\text { Mountains,Australia }\end{array}$ & & \\
\hline & & Ichkeul National Park, Tunisia & & \\
\hline & & $\begin{array}{l}\text { Wet Tropics of Queensland, } \\
\text { Australia }\end{array}$ & & \\
\hline & & $\begin{array}{c}\text { Area de Guanacaste, Costa } \\
\text { Rica }\end{array}$ & & \\
\hline \multirow{9}{*}{ Cultural } & \multirow{4}{*}{ Archaeological } & Chan Chan Zone, Peru & \multirow{4}{*}{$\begin{array}{l}\text { - The increasing frequency of } \\
\text { droughts or floods and changes in } \\
\text { water-table levels, in humidity } \\
\text { cycles, in time of wetness, in } \\
\text { groundwater, and soil chemistry }\end{array}$} & \multirow{4}{*}{$\begin{array}{l}\text { - Inducing crystallization and } \\
\text { dissolution of salts, thus } \\
\text { affecting buried archaeology as } \\
\text { well as wall paintings, frescos } \\
\text { and other decorated surfaces, } \\
\text { including rock art }\end{array}$} \\
\hline & & $\begin{array}{l}\text { Ivvavik/Vuntut/Herschel } \\
\text { Island,Canada }\end{array}$ & & \\
\hline & & Chavín, Peru & & \\
\hline & & $\begin{array}{l}\text { Golden Mountains of Altai, } \\
\text { Russian Federation }\end{array}$ & & \\
\hline & \multirow{5}{*}{ Historic Cities } & $\begin{array}{l}\text { The city of London, United } \\
\text { Kingdom }\end{array}$ & \multirow{5}{*}{$\begin{array}{l}\text { - } \quad \text { Desertification and salt weathering } \\
\text { - } \quad \text { Structural damage due to Increases } \\
\text { in the wind } \\
\text { - Post flooding and growth of } \\
\text { damaging micro-organisms such } \\
\text { as fungi }\end{array}$} & \multirow{5}{*}{$\begin{array}{l}\text { - } \quad \text { abandonment of property } \\
\text { - } \quad \text { The need for a strategic shift } \\
\text { from a reactive to a } \\
\text { proactive approach } \\
\text { The eventual loss of rituals } \\
\text { and cultural memory }\end{array}$} \\
\hline & & Venice and its Lagoon, Italy & & \\
\hline & & $\begin{array}{l}\text { Cesky Krumlov, Czech } \\
\text { Republic }\end{array}$ & & \\
\hline & & Timbuktu, Mali & & \\
\hline & & Ouadi Qadisha, Lebanon & & \\
\hline
\end{tabular}

Different type of the risks, stresses, and difficulties associated with putting general policies into practice reveals the fundamental need for reconsideration of traditional heritage policies. For climate activists and heritage policy-makers, increasing their understanding of priority actions, engagement of local communities and collaboration with scientists and scholars on the intersections is of great importance to diminish the additional stress on cultural heritage sites.

\subsection{The Potential of Climate Change for Changing the Concept}

In the specific context of the Convention, climate change increases many concerns that are significant for the future implementation of the Convention. Heritage sites are inscribed on the World Heritage List if they meet at least one criteria of outstanding universal value and also fulfil the conditions of integrity [43]. At present, if a site is threatened by severe and specific danger-both determined and potential - it can be listed in the List of World Heritage in Danger. The Convention also observes that if a property loses the characteristics which approved its inscription on the World Heritage List, it can be removed from the list.

Therefore, within the context of the convention, climate change poses an important issue while understanding that its inherent outstanding universal value may disappear due to its environmental and socio-economic impacts. Therefore, it is proper to assess whether the procedures described in the current Operational Guidelines for the Implementation of the World Heritage Convention are sufficient. 


\section{Discussion}

The study of the international charters and guides on conservation of cultural heritage show that the evolution of this concept has been based on the experience and evidence at world heritage sites. Over time, the meaning of cultural heritage in professional practice has developed from individual monuments to serial properties and sites, historic cities and cultural landscapes. The contemporary practice further extends the concept of heritage beyond tangible heritage, to the intangible dimensions of heritage as well [44]. This means the entirety of knowledge derived from the development and experience of practices, representations, expressions, and skills; and associated objects and spaces that communities recognize as part of their cultural heritage.

However, the emerging challenge in the conservation of cultural heritage is that climate change and its impacts are always in a degree of uncertainty and can only be interpreted based on forecasts. Perhaps one reason that UNESCO and its advisory bodies have not offered a clear solution to this threat is the uncertainty and long-term nature of climate change impacts on world heritage sites. In this regard, one can even refer to the submitted State Of Conservation, where change in weather pattern has not been considered a threat on the seventy-per cent of the reports. Table 2 illustrates how the magnitude impacts and diversity of World Heritage Sites have been a limiting factor in achieving a global model for tackling the issue by UNESCO. In line with this, in most research, conducted by UNESCO and its advisory, cultural heritage has been seen as a static concept rooted in the World Heritage Convention which necessarily raises the question of the effectiveness of climate-resilience strategies. In terms of cultural goods, one solution to enhance the resilience of heritage could be utilizing the novel methods that contribute to the sustainable use of heritage buildings such as rehabilitation, renovation or long-term monitoring of historic buildings [45]. However, sustainability of cultural heritage also depends on the environment and natural goods, which requires a larger scale to define heritage policy.

Climate change is transforming demographic balance, biological patterns, and the spread of multicultural societies across all human geography [46]. As a result, the concept of cultural heritage can no longer be defined as a frozen asset in time and, in fact, requires revision in determining its value assessment framework. Given that climate-resilient policies are developed with respect to valuation framework, rethinking the concept and debate assessment of valuation can be regarded as the most fundamental step in the implementation and effectiveness of climate-resilient policies.

According to Figures 1 and 2, each heritage site is threatened by specific climate change impacts, asking for different management decisions and actions that respond to trends and events, resource priorities, budget availability, management strategy, staff expertise, and visitor access.

In the spotlight of climate change, the availability and abundance of resources will be a critical factor in the sustainability of the landscape. At a glance, there are a variety of sources at the regional level that, if not adequately managed, threatens the persistence of the landscape in a changing climate. On the other hand, the fragility of socio-economic dynamics also threatens the sustainability of cultural heritage. So far, the traditional and conservative vision has defined heritage sites as a boundary that should remain in their traditional form under any circumstances. It is claimed that resilience thinking provides planning new attitudes that enable it to frame and address complexities and ambiguities inherent in the understanding and analysis of urban systems [47]. Climate change and a proper understanding of its impact require changes in attitudes toward cultural heritage before any planning and consideration of the various consequences that may follow traditional conservation principles, such as high maintenance costs or the risk of being abandoned.

It should, therefore, be clear how a changing and heterogeneous society should value cultural heritage at the territorial scale, and then develop climate-resilience policies. Since the scope of social change and landscape characteristics varies from place to place [48], cultural heritage should no longer be defined on a universal and traditional conservative basis, but by taking into account its role as a useful resource and an acceptable characteristic of landscape with real functions such as catalysts for enhancing the quality of life, culture and identity, or economic activities at territorial level. From an urban planning point of view, such an approach enables effective communication between stakeholders 
and efficient connection with other regional resources. Such a territorial planning and protection point of view gives cultural heritage a new role as a contributing factor for enhancing the landscape resilience capacity, rather than becoming a heavy burden on the government or local community. Thus, such an intelligent and dynamic approach to cultural heritage from conservation to protection, static to dynamic, valued to is valuing, and from isolated to contributor can play a constructive role to achieve a climate-resilient landscape as a larger and more complex whole. Such foresight may demand a development cycle framework at the territorial scale, as illustrated in Figure 3.

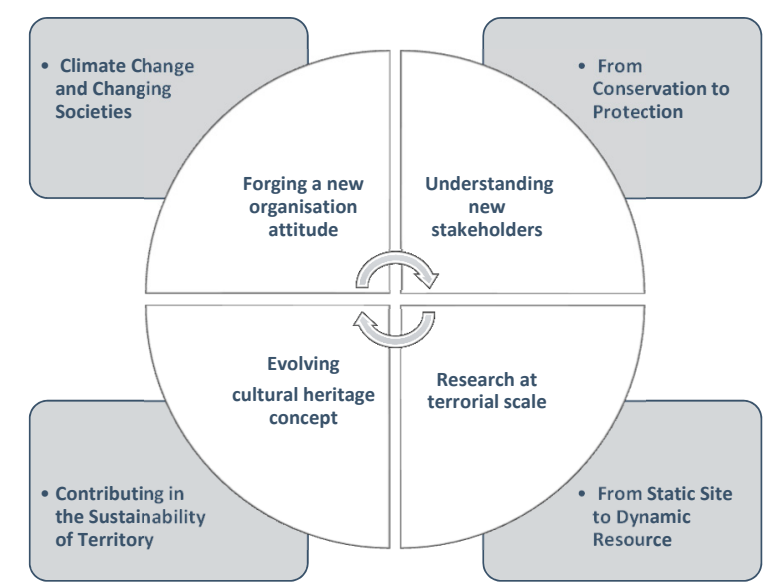

Figure 3. The cycle of defining cultural heritage as a territorial resource under the spotlight of climate change.

The main considerations in this cycle for reducing the impacts of climate change are:

- Forging a new organization attitude: Adopting a territorial planning approach for the protection of cultural heritage rather than a traditional conservation approach, through a more comprehensive and accurate understanding of the relationship between cultural heritages the natural resources;

- Understanding new stakeholders: Understanding how stakeholders value cultural heritage will be a key factor in the effectiveness of climate-resilience policies and the protection objectives;

- Research at territorial scale: Identifying the available and valid resources in the region and linking cultural heritage with natural resources;

- Evolving cultural heritage concept: Bridging the existing gaps and redefining cultural heritage from a dynamic and territorial planning point of view, Not only for its protection against climate change, but also emergency preparedness and disaster risk reduction.

Cultural heritage policies should focus on landscape and territorial scales, designed to inform natural and cultural resources and facility management. The key factor in redefining the protection policies include the synthesis of existing information, research, inventory and monitoring, and delivery of relevant information to managers and stakeholders to support decision-making. This approach encompasses four-step: connecting impacts and information; understanding scope; integrating practice; and learning and sharing [49]. Climate change often highlights long-standing preservation issues, rather than discovering new problems, but the save all approach to the historic environment needs to be re-evaluated [50]. Applying such a territorial vision also helps to manage priorities and regional decision-making in response to climate change, when in its traditional and conservative way of thinking cultural heritage becomes a heavy burden on the government or local community, as it needs significant funds for maintenance or restoration, funds that are never adequately or continuously available [51]. This approach can also provide further research opportunities on the topic and establish a connection between policymakers, heritage organizations, institutions, research centers, heritage site managers, academics, and others involved in the protection of cultural heritage [52]. Given the effective role of stakeholders in defining cultural heritage value [53] from the territorial point 
of view, this study also emphasizes the critical role of education and knowledge exchange across a wide range of stakeholders [42], including heritage management, trans disciplinary research, and climate science. This insight facilitates the engagement of the local community in protection of cultural heritage resources [54], and provide an influential base for redefining the cultural heritage concept and climate-resilience policies in the era of climate change. This policies should include new approaches that support multi-scale and multi-sector action rooted in the different expectations of a wide range of partners, expand the scope of community participation and engagement.

\section{Conclusions}

Over the past few decades, the World Heritage Convention has been an effective tool for defining cultural heritage and directing conservation policies all around the world. Whereas in the past the concept of cultural heritage has been developed based on the experienced issues in a relatively homogeneous community, the new challenge is that climate change and its effects on cultural heritage will always be based on uncertainty and forecasts. Referring to the diversity of climate change impacts on cultural heritage sites, this study questions the efficacy of climate-resilience policies based on the traditional concept of cultural heritage and its conservative approach. Underlying the need for a change in attitude, the findings of this study suggest a model that is valuing the validity of cultural heritage as a dynamic territorial resource in today's heterogeneous societies. In this model, the communication between planning institutions, stakeholders, and researchers organizes the concept of cultural heritage in relation to other regional resources and contributes to the effectiveness of climate-resilience policies at territorial level. Such a vision not only protects the territorial cultural heritage resources against climate change, in a broader vision, it also enhances the preparedness of landscape for natural disasters.

Author Contributions: Conceptualization, A.S.D. and M.S.; methodology, A.S.D. and I.P.; validation, M.S., A.S.D. and I.P.; writing—original draft preparation, A.S.D.; writing—review and editing, M.S., A.S.D. and I.P.; supervision, M.S.

Funding: This paper was developed in the frame of Italy-USA REsilient LANDscapes (RE-LAND), funded by the Ministry of Foreign Affairs and International Cooperation of Italy (MAECI), grant number of PGR06129.

Acknowledgments: The authors wish to express their special thanks to the US and Italian partners of the project for their precious collaboration.

Conflicts of Interest: The authors declare no conflict of interest.

\section{References}

1. Masson-Delmotte, V.; Zhai, P.; Pörtner, H.O.; Roberts, D.; Skea, J.; Shukla, P.R.; Pirani, A.; Moufouma-Okia, W.; Péan, C.; Pidcock, R.; et al. IPCC, 2018: Summary for Policymakers; IPCC: Geneva, Switzerland, 2018; Volume 1.

2. Smith, J.B.; Schellnhuber, H.-J.; Mirza, M.M.Q.; Fankhauser, S.; Leemans, R.; Erda, L.; Ogallo, L.; Pittock, B.; Richels, R.; Rosenzweig, C.; et al. Vulnerability to Climate Change and Reasons for Concern: a Synthesis; 2001; Available online: https://www.ipcc.ch/site/assets/uploads/2018/03/wg2TARchap19.pdf (accessed on 10 June 2019).

3. UN-HABITAT Cities and Climate Change: Global Report on Human Settlements. 2011. Available online: http://unhabitat.org/books/cities-and-climate-change-global-report-on-human-settlements-2011abridged/\# (accessed on 2 July 2019).

4. Sabbioni, C.; Brimblecombe, P.; Cassar, M. The Atlas of Climate Change Impact on European Cultural Heritage: Scientific Analysis and Management Strategies; Anthem Press: London, UK, 2010.

5. Leissner, J.; Kilian, R.; Kotova, L.; Jacob, D.; Mikolajewicz, U.; Broström, T.; Ashley-Smith, J.; Schellen, H.L.; Martens, M.; van Schijndel, J.; et al. Climate for Culture: assessing the impact of climate change on the future indoor climate in historic buildings using simulations. Herit. Sci. 2015, 3, 38. [CrossRef]

6. Henderson, M.; Seekamp, E. Battling the tides of climate change: The power of intangible cultural resource values to bind place meanings in vulnerable historic districts. Heritage 2018, 1, 220-238. [CrossRef]

7. Markham, A.; Osipova, E.; Lafrenz Samuels, K.; Caldas, A. World Heritage and Tourism in a Changing Climate; UNESCO Publishing: Paris, France, 2016. 
8. Kjellstrom, T.; Kovats, R.S.; Lloyd, S.J.; Holt, T.; Tol, R.S.J. The direct impact of climate change on regional labor productivity. Arch. Environ. Occup. Health 2009, 64, 217-227. [CrossRef] [PubMed]

9. Black, R.; Bennett, S.R.G.; Thomas, S.M.; Beddington, J.R. Climate change: Migration as adaptation. Nature 2011, 478, 447. [CrossRef] [PubMed]

10. Kim, H.-E. Changing climate, changing culture: adding the climate change dimension to the protection of intangible cultural heritage. Int. J. Cult. Prop. 2011, 18, 259-290. [CrossRef]

11. Adger, W.N.; Barnett, J.; Brown, K.; Marshall, N.; O'brien, K. Cultural dimensions of climate change impacts and adaptation. Nat. Clim. Chang. 2013, 3, 112. [CrossRef]

12. Colette, A. Case Studies on Climate Change and World Heritage; UNESCO Publishing: Paris, France, 2007.

13. IPCC. Climate Change 2014: Synthesis Report. Contribution of Working Groups I, II and III to the Fifth Assessment Report of the Intergovernmental Panel on Climate Change; IPCC: Geneva, Switzerland, 2014; ISBN 978-9-29-169143-2.

14. Fatorić, S.; Seekamp, E. Are cultural heritage and resources threatened by climate change? A systematic literature review. Clim. Chang. 2017, 142, 227-254.

15. Bandarin, F.; van Oers, R. The Historic Urban Landscape: Managing Heritage in an Urban Century; John Wiley \& Sons: Chichester, UK, 2012; ISBN 978-0-47-065574-0.

16. World Heritage Centre. The World Heritage Convention. Available online: https://whc.unesco.org/en/ convention/ (accessed on 2 June 2019).

17. Colette, A.; Cassar, M.; Committee, W.H. Others Climate Change and World Heritage: Report on Predicting and Managing the Impacts of Climate Change on World Heritage, and Strategy to Assist States Parties to Implement Appropriate Management Responses; UNESCO: Paris, France, 2007.

18. Kalman, H. Heritage Planning Principles and Process; Routledge: New York, NY, USA, 2014.

19. Harvey, D.C.; Perry, J. The Future of Heritage as Climates Change: Loss, Adaptation and Creativity; Routledge: London, UK, 2015; ISBN 978-1-31-753012-1.

20. Leal Filho, W.; Musa, H.; Cavan, G.; O’Hare, P.; Seixas, J. Climate Change Adaptation, Resilience and Hazards; Springer: New York, NY, USA, 2016.

21. Caldarice, O.; Brunetta, G.; Tollin, N. The Challenge of Urban Resilience: Operationalization. In Urban Resilience for Risk and Adaptation Governance; Springer: New York, NY, USA, 2019; pp. 1-6.

22. Sargolini, M.; Stimilli, F.; Scitaroci, M.O.; Radeljak, P. Modeli unaprjeđenja kulturnog krajolika zaobalja. In Proceedings of the Modeli revitalizacije i unaprjeđenja kulturnoga naslijeđa; arhitektonski fakultet, sveučilište $\mathrm{u}$ zagrebu: Zagreb, 2017; p. 40. Available online: http://scitaroci.hr/wp-content/uploads/2018/03/HERU2017_ zbornik.pdf (accessed on 23 September 2019).

23. Shirvani Dastgerdi, A.; De Luca, G. The Riddles of Historic Urban Quarters Inscription on the UNESCO World Heritage List. Int. J. Archit. Res. ArchNet-IJAR 2018, 12, 152-163. [CrossRef]

24. Cleere, H. The concept of 'outstanding universal value'in the World Heritage Convention. Conserv. Manag. Archaeol. Sites 1996, 1, 227-233. [CrossRef]

25. Shirvani Dastgerdi, A.; De Luca, G. Specifying the Significance of Historic Sites in Heritage Planning. Conserv. Sci. Cult. Herit. 2018, 18, 29-39.

26. Stovel, H. Effective use of authenticity and integrity as world heritage qualifying conditions. City Time 2007, 2,3 .

27. Tomlan, M.A. Historic Preservation: Caring for Our Expanding Legacy; Springer: New York, NY, USA, 2015; ISBN 978-3-31-904975-5.

28. Shirvani Dastgerdi, A.; De Luca, G. Strengthening the city's reputation in the age of cities: an insight in the city branding theory. City, Territ. Archit. 2019, 6, 1-7. [CrossRef]

29. Shirvani Dastgerdi, A.; De Luca, G. Boosting city image for creation of a certain city brand. Geogr. Pannonica 2019, 23, 23-31. [CrossRef]

30. Poria, Y.; Reichel, A.; Cohen, R. Tourists perceptions of World Heritage Site and its designation. Tour. Manag. 2013, 35, 272-274. [CrossRef]

31. Shirvani Dastgerdi, A.; De Luca, G. Joining Historic Cities to the Global World: Feasibility or Fantasy? Sustainability 2019, 11, 2662. [CrossRef]

32. Alsalloum, A. Rebuilding and Reconciliation in Old Aleppo: The Historic Urban Landscape Perspectives. In Reshaping Urban Conservation; Springer: Singapore, 2019; pp. 57-77. 
33. Shirvani Dastgerdi, A.; De Luca, G. Religious differences and radical spatial transformations in historic urban landscapes. Conserv. Sci. Cult. Herit. 2019, 19, 1-14.

34. Shirvani Dastgerdi, A.; De Luca, G. Planning with Minorities for Rehabilitating Majority of Historic Sites. Int. J. Minor. Gr. Rights 2019, 26, 1-13.

35. World Heritage Centre Advisory Bodies. Available online: http://whc.unesco.org/en/faq/9/ (accessed on 10 August 2019).

36. Cassar, M.; Young, C.; Weighell, T.; Sheppard, D.; Bomhard, B.; Rosabal, P. Predicting and Managing the Effects of Climate Change on World Heritage a Joint Report from the World Heritage Centre, Its Advisory Bodies, and a Broad Group of Experts to the 30th Session of the World Heritage Committee, Vilnius; University College of London: London, UK, 2006.

37. UNESCO. World Heritage Committee Decision 32 COM 7A.32 (31 March 2009) WHC08/32.COM/24Rev Para 5; UNESCO: Paris, France, 2009.

38. World Heritage Centre 06/30.COM/7.1. Available online: http://whc.unesco.org/archive/2006/whc06-30com07.1e.doc (accessed on 12 June 2019).

39. Francioni, F.; Lenzerini, F. The 1972 World Heritage Convention. A Commentary, 1st ed.; Oxford University Press: Oxford, UK, 2008; ISBN 0199291691.

40. Sherwood, G. Meta-synthesis: merging qualitative studies to develop nursing knowledge. Int. J. Hum. Caring 1999, 3, 37-42. [CrossRef]

41. Siddaway, A. What is a systematic literature review and how do I do one. Univ. Stirling 2014, 1, 1.

42. ICOMOS. The Future of Our Pasts: Engaging Cultural Heritage in Climate Action; ICOMOS: Paris, France, 2019.

43. World Heritage Committee. The Operational Guidelines for the Implementation of the World Heritage Convention; World Heritage Committee: Paris, France, 2017.

44. Sargolini, M. Cultural itineraries and slow path. Historical and environmental resources for the territorial planning. In Carmine Gambardella. le vie dei Mercanti; La scuola di pitagora: Napoli, 2014; p. 37. Available online: http://www.leviedeimercanti.it/wp-content/uploads/2015/11/Pagine-da-sintesi-Atti-XII-Forum.pdf (accessed on 5 June 2019).

45. Haugen, A.; Bertolin, C.; Leijonhufvud, G.; Olstad, T.; Broström, T. A methodology for long-term monitoring of climate change impacts on historic buildings. Geosciences 2018, 8, 370. [CrossRef]

46. O'Brien, K. Responding to environmental change: A new age for human geography? Prog. Hum. Geogr. 2011, 35, 542-549. [CrossRef]

47. Sharifi, A.; Yamagata, Y. Resilience-oriented urban planning. In Resilience-Oriented Urban Planning; Springer: Champaign, IL, USA, 2018; pp. 3-27.

48. Trombulak, S.C.; Baldwin, R.F. Landscape-Scale Conservation Planning; Springer: Dordrecht, The Netherlands, 2010; ISBN 978-9-04-819574-9.

49. Melnick, R.Z.; Kerr, N.P.; Malinay, K.; Burry-Trice, O. Climate change and cultural landscapes: a guide to research, planning, and stewardship. Dep. Landsc. Archit. Univ. Oregon Univ. Oregon 2017, 66. [CrossRef]

50. Cassar, M. Climate Change and the Historic Environment. 2005. Available online: http://discovery.ucl.ac.uk/ 2082/1/2082.pdf (accessed on 8 July 2019).

51. Feilden, B.M.; Jokilehto, J. Management Guidelines for World Cultural Heritage Sites. 1998. Available online: https://www.iccrom.org/sites/default/files/2018- (accessed on 12 August 2019).

52. Sesana, E.; Gagnon, A.; Bertolin, C.; Hughes, J. Adapting cultural heritage to climate change risks: perspectives of cultural heritage experts in Europe. Geosciences 2018, 8, 305. [CrossRef]

53. Chmutina, K.; Jigyasu, R.; Bosher, L. Understanding the impacts of climate change on cultural heritage buildings: A case of York, UK. In Proceedings of the CIB World Building Congress: Intelligent Built Environment for Life, Tampere, Finland, 30 May-3 June 2016.

54. Bertolin, C. Preservation of Cultural Heritage and Resources Threatened by Climate Change. Geosciences 2019, 9, 250. [CrossRef]

(C) 2019 by the authors. Licensee MDPI, Basel, Switzerland. This article is an open access article distributed under the terms and conditions of the Creative Commons Attribution (CC BY) license (http://creativecommons.org/licenses/by/4.0/). 